\title{
Physical properties of wood in thinned Scots pines (Pinus sylvestris L.) from plantations in northern Spain
}

\author{
Guillermo RIESCo MUÑoz ${ }^{1 *}$, María A. SoILÁN CAÑAS ${ }^{1}$, Roque RodRíGUEZ SoALlEIRO $^{2}$ \\ ${ }^{1}$ Departamento de Ingeniería Agroforestal, University of Santiago de Compostela, Escuela Politécnica Superior, Campus Universitario s/n., \\ 27002 Lugo, Spain \\ ${ }^{2}$ Departamento de Producción Vegetal, University of Santiago de Compostela, Escuela Politécnica Superior, Campus Universitario s/n., \\ 27002 Lugo, Spain
}

(Received 3 September 2007; accepted 2 April 2008)

\begin{abstract}
-
- The physical properties of wood and the associated variations within and between trees were evaluated by analysing 770 small specimens of clear wood from 11 Pinus sylvestris L. trees thinned from 3 plantations.

- Within-tree variations in basic density or volumetric shrinkage increased with cambial age and decreased with increasing ring width. The effect of the height in the stem on wood properties was considered indirect and height was not included as an explanatory variable in the mixed models proposed to estimate basic density and volumetric shrinkage.

- The models had random components for the intercept parameter and explained $52.5 \%$ of the total variance in basic density and $56 \%$ of the total variance in volumetric shrinkage. Linear shrinkage in the direction of the grain was extremely variable.

- Between-tree variation and between-plot variation in the physical properties of wood were high, considering that all trees sampled were growing in similar sites and stands. It would then be desirable to predict physical properties of wood on living trees in order to use the quality of wood as a criterion for timber tree selection in thinnings.
\end{abstract}

Scots pine / Pinus sylvestris / wood properties / thinning

Résumé - Propriétés physiques du bois de pin sylvestre (Pinus sylvestris L.) issu d'éclaircie dans des plantations du nord de l'Espagne.

- Les propriétés physiques du bois et leurs variations intra et inter arbres ont été évaluées à partir de l'analyse de 770 éprouvettes de bois sans nœuds de 11 arbres d'éclaircie répartis sur 3 sites.

- La densité et le retrait volumétrique augmentaient dans chaque arbre avec l'âge du cambium et diminuaient avec la largeur de cerne. On a considéré que la hauteur dans la tige n'avait qu'un effet indirect sur les propriétés du bois, aussi la hauteur a-t-elle été exclue des variables explicatives dans les modèles mixtes proposés pour estimer la densité et le retrait volumétrique.

- Ces modèles présentent une composante aléatoire pour le terme constant et peuvent expliquer $52,5 \%$ de la variabilité totale de la densité basique et $56 \%$ de la variabilité totale du retrait volumétrique.

- Le retrait longitudinal est extrêmement variable. La variation entre arbres et entre sites est très importante, compte tenu de la similarité des peuplements et sites étudiés.

pin sylvestre / Pinus sylvestris / propriétés du bois / éclaircie

\section{INTRODUCTION}

The area occupied by Scots pine (Pinus sylvestris L.) in Spain has been greatly extended through afforestation of 650000 ha of land, mainly in northern Spain (DGCONA, 2002). The only way of enhancing stand development after canopy closure is by manipulation of stand density through thinning (Malcolm, 1997). Thinning is also necessary to avoid stand stagnation, reduce mortality rates (Bravo-Oviedo et al., 2006), promote long-term wind and snow stability (Montero et al., 2001) and enhance the amenity of the stand. It has even been shown that thinning can produce improvements in ring width without any negative impacts on wood properties

*Corresponding author: riescomu@lugo.usc.es
(Guller, 2007). Intense thinning programmes have been therefore developed for pine plantations in recent years. This has allowed faster diameter growth, as demonstrated for some Spanish provenances of Scots pine (Gómez Loranca et al., 1996).

Precommercial thinning is generally avoided because of the costs involved, and the first thinning is usually delayed until commercial timber can be obtained by mechanized harvesting. The first thinnings are usually carried out by removing every seventh to thirteenth row (depending on the slope), while the remaining rows are thinned selectively from below (Rojo et al., 2005). The wood thus harvested is mainly used as a raw material for the chipboard industry because of its small diameter, but higher grade wood from thinnings is also used in sawmills. It has been shown that the application of heavy thinning may 
Table I. Information about sampled trees.

\begin{tabular}{|c|c|c|c|c|c|c|}
\hline Plot & Trees & Sample size & Age (years) & Diameter $(\mathrm{cm})$ & Height $(\mathrm{m})$ & Range of sampled heights (m) \\
\hline & 1 & 17 & 28 & 19.7 & 11.7 & 0 to 5.0 \\
\hline Rebordela & 2 & 32 & 28 & 24.3 & 12.8 & 0 to 7.5 \\
\hline $\mathrm{SI}=14 \mathrm{~m}$, & 3 & 31 & 28 & 19.2 & 12.2 & 0 to 7.5 \\
\hline \multirow[t]{2}{*}{$\mathrm{SN}=1250$ stems ha ${ }^{-1}$} & 4 & 32 & 28 & 28.9 & 12.9 & 0 to 7.5 \\
\hline & 5 & 33 & 28 & 34.0 & 13.0 & 0 to 7.5 \\
\hline Torviso & 6 & 26 & 44 & 16.0 & 9.1 & 0 to 4.2 \\
\hline $\mathrm{SI}=12 \mathrm{~m}$ & 7 & 43 & 44 & 20.0 & 14.3 & 0 to 8.4 \\
\hline $\mathrm{SN}=1600$ stems ha ${ }^{-1}$ & 8 & 77 & 44 & 33.6 & 17.5 & 0 to 8.4 \\
\hline Seoane & 9 & 245 & 44 & 31.8 & 20.3 & 0 to 14.2 \\
\hline $\mathrm{SI}=14 \mathrm{~m}$ & 10 & 113 & 44 & 13.5 & 16.5 & 0 to 11.3 \\
\hline $\mathrm{SN}=1600$ stems ha $^{-1}$ & 11 & 121 & 44 & 18.9 & 16.4 & 0 to 11.3 \\
\hline
\end{tabular}

Site index (SI) was evaluated as the dominant height at a reference age of 30 years. SN is the stem number of the stand before thinning.

not have a direct effect in reducing the density of the wood that is subsequently produced (Mörling, 2002).

Wood density is considered an important characteristic in defining wood quality because it correlates reasonably well with a number of the characteristics that are important in various end uses of wood (West, 2006). It has been shown that wood density tends to increase toward the outer parts of the stem in most of the species used in major forestry plantations, such as Scots pine. The inverse relationship between the thickness of the annual growth ring and the respective wood density, and the direct relationship between the ring number from the pith and density have allowed development of models that can be used in combination with taper functions to estimate tree biomass and carbon stocks (Kellomäki et al., 1999).

It is well known that dense wood is subject to more shrinkage than less dense wood when it is dried in kilns for use, because of the higher water content of the thicker cell walls (West, 2006). We consider that there is still a need to investigate the relationships between shrinkage variables and density, as well as the variation in volumetric shrinkage along the stem.

Physical properties of wood from thinning are conditioned by the large expected proportion of juvenile wood in small timber, which is characterized by higher ring width, higher longitudinal shrinkage and lower specific gravity (Panshin and de Zeeuw, 1980). Scots pine is considered to show a clear transition between juvenile and mature wood, which has been estimated at a cambial age of 22 years (Mutz et al., 2004; Zobel and van Buijtenen, 1989).

Most studies previously carried out in Spain refer to average values and ranges of variation in physical properties in naturally regenerated stands (Gutiérrez Oliva and Plaza, 1967; Nájera and Peraza, 1960); it is well known that Scots pine wood derived from thinning in such stands is poorer in quality than the wood from regeneration cuttings (Fernández-Golfín et al., 1997), mainly due to the higher presence of sapwood and juvenile wood. It has been shown that diameter growth in plantations in Spain is greater than that corresponding to natural stands when the afforestation is carried out in suitable sites (Martínez Chamorro, 2004), which raises questions about the quality of the wood produced.
The aims of the present study were: (1) to describe the physical properties, namely density and dimensional stability, of Scots pine wood obtained from thinned trees in plantations in northern Spain; (2) to study the within-tree variations in physical properties according to cambial age, ring width and height in the stem; (3) to obtain information about between-tree variation in density and other wood properties, based on the physical properties of small specimens.

\section{MATERIALS AND METHODS}

\subsection{Data collection}

Wood samples were taken from eleven trees harvested during thinning. The trees were aged 28-44 years and the breast height diameter over bark was between 14 and $34 \mathrm{~cm}$. The trees were located in three plots, classified with a site index of between 12 and $14 \mathrm{~m}$ of top height at age 30, according to regional yield tables (Martínez Chamorro, 2004). The main characteristics of the plots (where the stand was in fact being thinned) and individual attributes for each tree are shown in Table I. Cross-sectional discs were obtained from the stump level to the maximum height at which specimens could be obtained safely (70\% of the total height on average) at intervals of 2 to $2.5 \mathrm{~m}$, according to the log length considered in each site. The height at which the trees were sampled was therefore not exactly the same in all trees. The range of sampled heights per tree is shown in Table I.

To obtain the test material, the discs were cut into small prisms, the edges of which ran parallel (as far as possible) to the grain of wood. The target dimensions of the prisms were length, $4 \mathrm{~cm}$, transverse section, $2 \times 2 \mathrm{~cm}$, and length, $2 \mathrm{~cm}$, transverse section, $4 \times 4 \mathrm{~cm}$. In each cross section, the samples were taken from pith to bark to maximize the sample size and to obtain the entire range of variation in cambial age, as is illustrated in Figure 1. The number of specimens taken from each cross section thus depended directly on the diameter. A total of 252 small and 518 large specimens were taken, with an average of 70 specimens collected from each tree. Only defect-free pieces (straight grain, absence of defects such as knots, checks, bark, resin pockets or reaction wood) were selected for testing (Gómez Loranca et al., 1996). Specimens presumably of juvenile wood (pieces with very round rings adjacent to the pith) were also included in trials because this type of wood is frequent in young pine trees (Aguiar et al., 2003; Jayawickrama, 2001). 


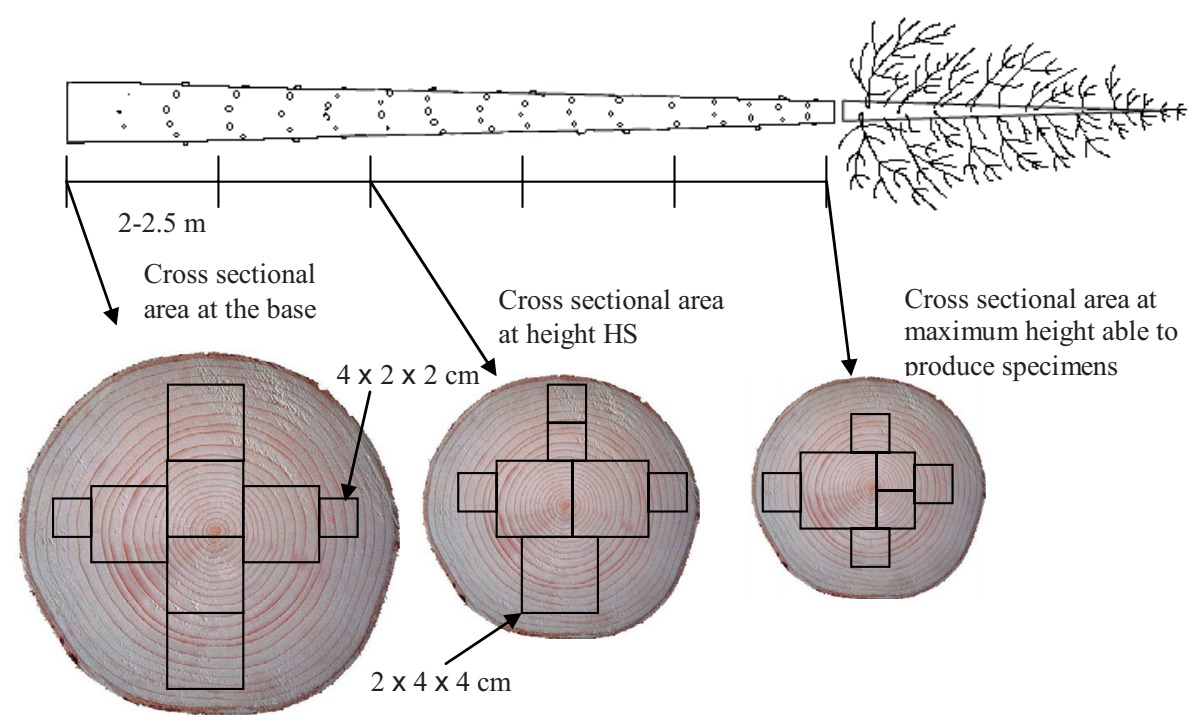

Figure 1. Pattern of sampling of specimens along the stem of a tree. The lower, upper and an intermediate cross section are shown in detail. HS is the height in the stem.

Table II. Total sample size and distribution among trees.

\begin{tabular}{|c|c|c|c|c|c|c|c|c|c|c|c|c|}
\hline \multirow[b]{2}{*}{ Variable } & \multicolumn{11}{|c|}{ Sample size for each tree } & \multirow{2}{*}{$\begin{array}{c}\text { Total } \\
\text { sample size }\end{array}$} \\
\hline & 1 & 2 & 3 & 4 & 5 & 6 & 7 & 8 & 9 & 10 & 11 & \\
\hline Basic density $\left(\mathrm{kg} \mathrm{m}^{-3}\right)$ & 15 & 30 & 30 & 30 & 31 & 26 & 39 & 68 & 244 & 104 & 114 & 731 \\
\hline Volumetric shrinkage (\%) & 15 & 30 & 30 & 30 & 28 & 26 & 40 & 69 & 245 & 106 & 121 & 740 \\
\hline Radial shrinkage (\%) & 4 & 8 & 10 & 15 & 12 & 0 & 0 & 0 & 0 & 0 & 0 & 49 \\
\hline Tangential shrinkage (\%) & 4 & 8 & 10 & 15 & 12 & 0 & 0 & 0 & 0 & 0 & 0 & 49 \\
\hline Axial shrinkage (\%) & 10 & 18 & 15 & 10 & 18 & 8 & 11 & 22 & 64 & 34 & 29 & 239 \\
\hline
\end{tabular}

The physical properties of the wood were studied by considering the standard methods proposed by the International Organization for Standardization (ISO), and European Norms (EN). To determine the main physical properties, the weight and the three dimensions of each specimen were measured at three different wood moisture contents (saturation, $12 \%$ and $0 \%$ ). The air-dry density at $12 \%$ equilibrium moisture content and the basic density were calculated according to current standards (EN 408:2003, EN 384:2004 and ISO 3131:1975). The equilibrium moisture content was determined by the oven desiccation method and difference in weights (EN 13183-1:2002). Shrinkage and shrinkage anisotropy were studied because deformation properties strongly affect mechanical wood processing (Riekkinen et al., 2005). The volumetric shrinkage and the linear shrinkage in the three main directions of the wood were expressed as a percentage of the dimension in the oven-dried state. The similarity of tangential and radial shrinkage were evaluated considering both anisotropic shrinkage (ratio of tangential to radial shrinkage) and absolute anisotropy (tangential minus radial shrinkage) because the difference provides a much better indication of the risk of deformation of the wood while drying, than the ratio itself (Rijsdijk and Laming, 1994).

The variables related to shrinkage in an axial direction were only assessed in $4 \times 2 \times 2 \mathrm{~cm}$ specimens and variables related to shrinkage in transverse direction were only assessed in $2 \times 4 \times 4 \mathrm{~cm}$ specimens with the rings parallel to the edges, and only in one site. The width of annual growth rings was also assessed in each saturated specimen. This was computed as the dimension of the longest radial segment in the transverse section divided by the number of complete rings in the section, and taking an average for the two transverse faces of the spec- imen. The cambial age in each specimen was measured as the number of annual growth rings from pith to the centre of the specimen. Finally, the test specimens were stained with a solution of methyl orange $(1 \%)$ to detect the heartwood. The sample size per tree obtained for each of the major physical variables studied is shown in Table II.

\subsection{Statistical methods}

The relationships between quantitative variables were tested with Pearson's linear coefficient of correlation $(R)$. A one-factor analysis of variance was carried out to test statistically significant relationships between quantitative and qualitative variables.

To detect compression wood in the specimens a cluster analysis was performed considering four explanatory variables: height in the stem, basic density, ring width and the ratio between volume shrinkage and basic density. These variables were previously standardized and the FASTCLUS procedure of SAS/STAT, based on the algorithm of the $k$-means, used (SAS Institute, 2004). The number of clusters considered was the minimum one providing a high approximate expected $R^{2}$ and the possibility to clearly identify a cluster to be representative of this type of wood.

A mixed model (1) was tested for basic density $\left(B D_{i j}\right)$ with radial growth criteria (i.e. ring number from the pith, $C A$, and ring width, $R W$ ) as fixed explanatory variables, and excluding those specimens in which compression wood was detected. To explore the general form of the model, a linear regression was fitted to the whole set of data selecting the explanatory variables with a stepwise procedure. After 


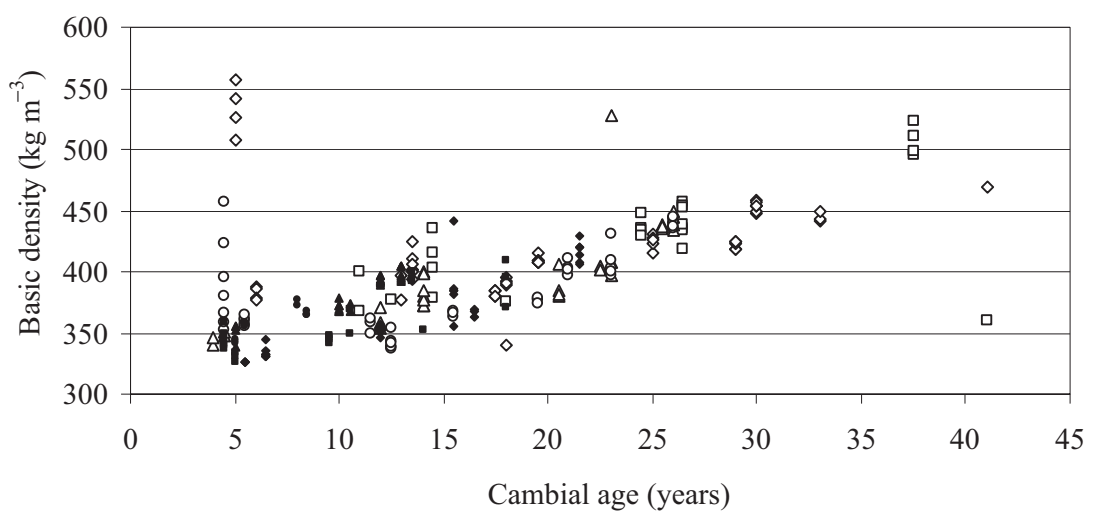

Figure 2. Basic density in relation to age from the pith for different cross sections in tree $9 . \diamond=$ cross section 1 , $\square=$ cross section $2, \Delta=$ cross section $3, \circ=$ cross section $4, \bullet=$ cross section $5, \boldsymbol{\square}=$ cross section $6, \boldsymbol{\Delta}=$ cross section $7, \bullet=$ cross section 8 .

fitting the model tree by tree, only the intercept was considered as a random component in the mixed model.

$$
B D_{i j}=a_{0}+\alpha_{i}+a_{1} C A_{i j}+a_{2} C A_{i j}^{2}+a_{3} \frac{1}{R W_{i j}}+\varepsilon_{i j}
$$

The index $i$ denotes the $i$ th tree and $j$ the $j$ th specimen; $a_{0}, a_{1}, a_{2}$ and $a_{3}$ are fixed effects. The random tree effects $\left(\alpha_{i}\right)$ were assumed to follow a multivariate normal distribution $N(0, G)$ with variancecovariance matrix $G$ and the residual errors $\left(\varepsilon_{i j}\right)$ were assumed to be within-tree auto-correlated according to a first-order autoregressive process, and inter-tree independent. This form is similar, except for the inclusion of $C A^{2}$ as an explanatory variable, to that considered by Guilley et al. (2004)

A similar approach was considered for modelling the distribution of volumetric shrinkage (VS):

$$
V S_{i j}=b_{0}+\beta_{i}+b_{1} C A_{i j}+b_{2} C A_{i j}^{2}+b_{3} \frac{1}{R W_{i j}}+\varepsilon_{i j}
$$

Fixed and random effects were tested by the method of restricted maximum likelihood with the MIXED procedure of SAS/STAT (Littell et al., 1996). The contribution of each tested factor was evaluated by splitting the total variability in wood density into the variation component explained by the fixed effects, variation due to random effects, and residual variance.

\section{RESULTS AND DISCUSSION}

\subsection{Presence of juvenile, mature and compression wood}

The specimens displayed a large range of annual ring widths (from 1.0 to $9.3 \mathrm{~mm}$, mean value of $3.8 \mathrm{~mm}$ ), with a higher mean value than reported in similar studies with wood specimens obtained from plantations: $3.2 \mathrm{~mm}$ (FernándezGolfín and Díez, 1994) and 3.1 mm (Fernández-Golfín et al., 1997). In addition, approximately $80 \%$ of the specimens contained juvenile wood. Both characteristics, i.e. wide annual rings and presence of juvenile wood, are common in young trees initially planted with a large spacing (Gjerdrum, 2003), in which section growth is expected to be high. Sapwood predominated because heartwood formation can be initiated until ages of up to 50 years (Gómez Loranca et al., 1996; Kollmann, 1951; Mörling and Valinger, 1999).

Even if three wood density variables were calculated (airdry, oven-dry and basic density), the last one produced more consistent results and was the only one kept in the final analyses. The plots of basic density against cambial age for different cross sections along the stem showed an increasing trend from pith to bark, with some cases of very dense wood located at the base of the stem and near the pith. The distribution of basic density for different cross sections of tree 9 is shown in Figure 2, with the effect of compression wood apparent at the stem butt.

One of the first six clusters formed considering the physical properties of the whole sample was representative of this type of wood, and accounted for $59.7 \%$ of the total variation in data. Overall, 50 specimens were grouped in this category, with the following means and standard deviations for the explanatory variables: ring width, $3.9 \mathrm{~mm}$ (1.3); height in stem, $1.4 \mathrm{~m} \mathrm{(1.6);}$ basic density, $487.1 \mathrm{kgm}^{-3}$ (41.1); volume shrinkage and basic density ratio, $0.021(0.0025)$.

These values indicate problems of mechanical stability in the young trees and development of basal sweep when smaller trees strive to regain a vertical position. In fact, compression wood in the area surrounding the pith appears in most conifer trees (Rune and Warensjö, 2002). Specimens from each of the eleven trees analysed contained compression wood, although the proportion of such specimens varied greatly between trees, from $3.2 \%$ of the total specimens in tree number 4 to $23.2 \%$ in tree number 7. Further analysis of variation of physical properties along the stem was carried out excluding these specimens.

\subsection{Within-tree variation in physical properties}

The variation in density within the stem was analysed by means of three within-tree variables related to the position in the trunk: height in stem, annual growth ring width and cambial age. These variables have been reported to be related to density (Kollmann, 1951). The trend in basic density along the stem (excluding compression wood) and in relation to cambial age and ring width is shown in Figures 3, 4 and 5. 


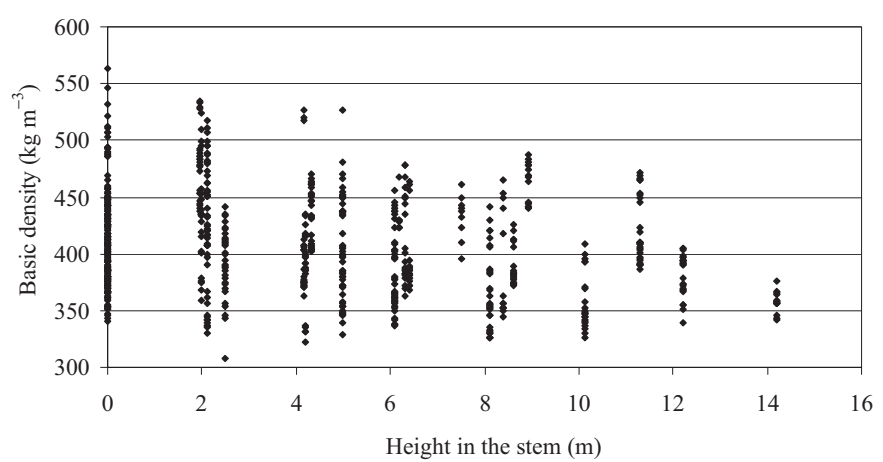

Figure 3. Variation in basic density along the height in the stem.

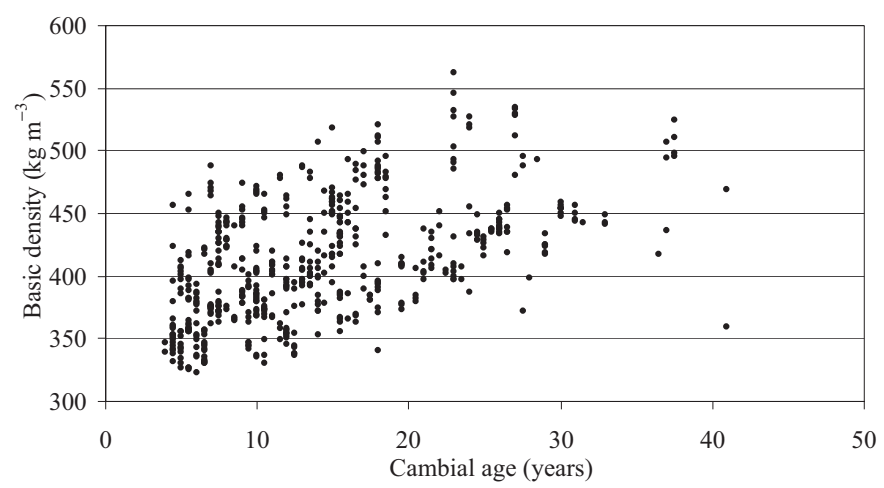

Figure 4. Variation in basic density depending on the ring number from the pith.

Density decreased from the base to the top of the stem. The minimum density at every height was roughly constant and very rarely below $350 \mathrm{~kg} \mathrm{~m}^{-3}$, the lowest limit for density of most species (Forest Products Laboratory, 1999). In addition, the slight reduction in density with increasing height (the mean value of basic density only decreased $72 \mathrm{~kg} \mathrm{~m}^{-3}$ from the base to $14.2 \mathrm{~m}$ height) indicates that it may be feasible for the timber industry to use second and third logs from thinned trees.

The width of annual growth rings in softwoods mainly depends on site and is correlated to wood density (Louzada, 1991). As density is affected by the cambial age, the effect of ring width on density is therefore indirect (Kininmonth and Whitehouse, 1991). The experimental evidence revealing that wood with wide annual rings possesses different properties than wood with narrow rings can thus be explained by taking into account the proportion of juvenile and mature wood in both cases (Louzada and Fonseca, 1991). The analysis of plotted data does not allow assumption of a linear pattern of variation in the case of ring width and cambial age. The lowest basic density (about $350 \mathrm{~kg} \mathrm{~m}^{-3}$ ) was obtained in specimens of ring width between 4.0 and $6.0 \mathrm{~mm}$.

The variation in the volumetric shrinkage with explanatory variables such as height in the stem, cambial age and ring width is similar to that of basic density, because of the strong correlation between these two variables. Density is often used as an indicator of wood quality because of its relationship to some important properties, namely those related to dimen-

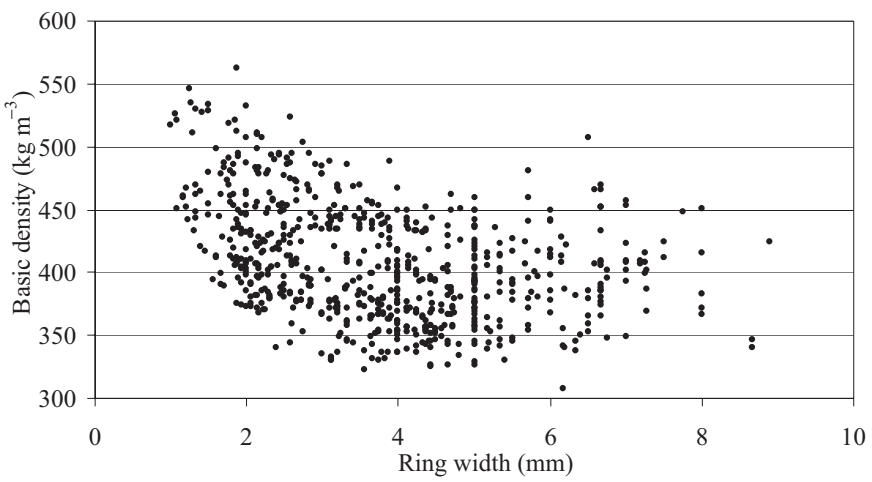

Figure 5. Variation in basic density with ring width.

sional stability on varying the moisture content. In the present study the relationship between wood density and volumetric and axial shrinkage were both positive and highly significant (see Tab. III).

The effect of density on wood dimensional stability was consistent with previous reports for mature wood in conifers. Density, for example, affects volumetric shrinkage (Gutiérrez Oliva et al., 1997; Louzada, 1991). The coefficients of correlation revealed that basic density would be a better predictor of volumetric stability than ring width, although this variable was significantly correlated with shrinkage variables other than basic density (Tab. III). Density is considered a better predictor of wood quality than ring width in softwoods from southern Europe, as demonstrated for Pinus sylvestris (Fernández-Golfín and Díez, 1994; Mazet and Nepveu, 1991), Pinus pinaster (Louzada, 2003) and other softwood species such as Abies alba, Picea abies (Mazet and Nepveu, 1991) and Pseudotsuga menziesii (Louzada and Fonseca, 1991).

Due to the small number of samples taken for measurement of radial and tangential shrinkage, it was not possible to study the variation along the stem and cross sections. There was a close relationship between these variables and volumetric shrinkage, and a negative one between radial shrinkage and ring width.

\subsection{Between-tree variation in physical properties}

The comparison of physical properties among trees was made for the stem base specimens corresponding to heartwood, assuming that a cambial age of less than 22 years would define this area. Values of radial and tangential shrinkage were excluded from the analysis, because there was less data available for these variables. There were highly significant differences among trees (even in a sample of young trees growing in similar sites) in terms of basic density $(p<0.0001)$ and volumetric shrinkage $(p<0.0001)$, and to a lesser extent, axial shrinkage $(p=0.003)$. Differences between zones were significant for basic density $(p<0.0001)$, and to a lesser extent for volumetric shrinkage $(p=0.017)$ and axial shrinkage $(p=0.033)$. The between-tree variation in basic density can be observed in Figure 6: the mean basic density of heartwood at the stem base of the tree with the lightest wood 
Table III. Coefficients of correlation $(R)$ for density and other properties of the Scots pine wood studied.

\begin{tabular}{|c|c|c|c|c|c|}
\hline & Height in the stem & Ring width & Cambial age & Basic density & Volumetric shrinkage \\
\hline Cambial age & $-0.447^{\mathrm{a}}$ & $-0.398^{\mathrm{a}}$ & - & - & - \\
\hline Basic density & $-0.243^{\mathrm{a}}$ & $-0.376^{\mathrm{a}}$ & $0.535^{\mathrm{a}}$ & - & - \\
\hline Volumetric shrinkage & $-0.363^{\mathrm{a}}$ & $-0.344^{\mathrm{a}}$ & $0.579^{\mathrm{a}}$ & $0.624^{\mathrm{a}}$ & - \\
\hline Radial shrinkage & Ns & $-0.481^{b}$ & $\mathrm{Nd}$ & Ns & $0.667^{\mathrm{a}}$ \\
\hline Tangential shrinkage & Ns & Ns & $\mathrm{Nd}$ & Ns & $0.670^{\mathrm{a}}$ \\
\hline Longitudinal shrinkage & $-0.208^{b}$ & $0.280^{\mathrm{a}}$ & $-0.143^{c}$ & $0.486^{\mathrm{a}}$ & \\
\hline
\end{tabular}

${ }^{\mathrm{a}} p<0.0001 .{ }^{\mathrm{b}} p<0.05 .{ }^{\mathrm{c}} p<0.10 . \mathrm{Nd}=$ no data available. Ns $=$ not significant.

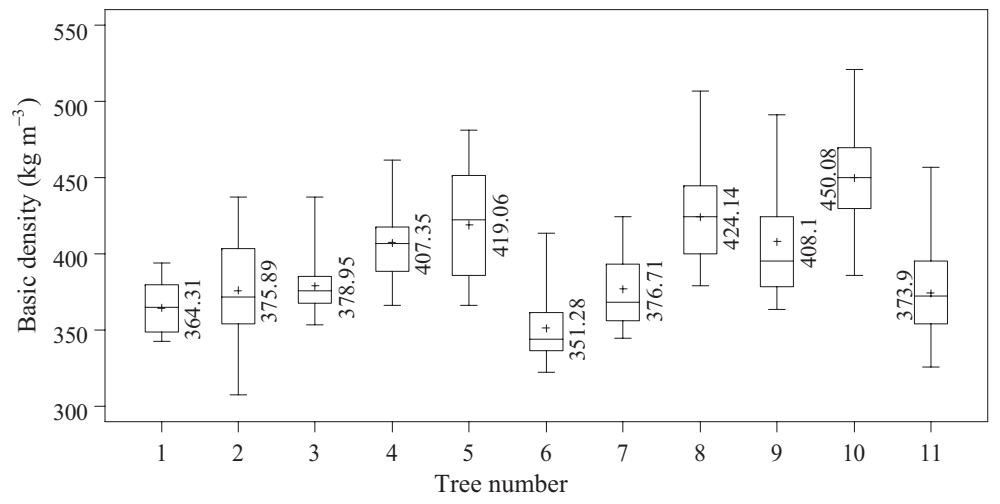

Figure 6. Between-tree variation in basic density of heartwood specimens located at the stem base. Mean values, standard deviations and maximum and minimum values are shown for each tree.

was $351.3 \mathrm{~kg} \mathrm{~m}^{-3}$, and the highest density was $450.1 \mathrm{~kg} \mathrm{~m}^{-3}$, in a tree similar in diameter and age to that with the lowest density. In fact, no relationships between any individual tree attribute and the values of basic density of heartwood were found. These results were consistent with those of previous studies in which density was found to be affected by individual attributes, with large differences in density among trees, and particularly marked differences in adult trees (Louzada, 1991; Louzada and Fonseca, 1991). Although only three sites were investigated, the effect on the basic density, volumetric and axial shrinkage appears to be important, but lower than that of individual trees, thus confirming that environmental variables such as location, site index and treatment affect wood quality (Kollmann, 1951).

The values of the coefficients of correlation calculated for individual trees showed that cambial age and ring width were more frequently related to density than height in the stem. Even if the coefficient of correlation between basic density and height in the stem was negative and highly significant in the complete sample (Tab. III), trees 3, 4 and 5 showed a positive relationship between height in the stem and basic density.

The intra-tree relationships between basic density and shrinkage variables were not always clear, not even the relationships among longitudinal shrinkage and other physical variables. Furthermore, the relationship between ring width and radial shrinkage variables was not always significant when each tree was considered individually. Only the direct relationships between volumetric shrinkage and each of the two transverse shrinkage variables remained significant at a single tree level.
The effect of individual features on the physical properties of Scots pine must be considered in potential forest management methods, provided that the overall goal is the production of valuable timber. It would therefore be useful to identify relationships among physical properties of wood and easily measured individual tree variables, to be able to predict wood quality from tree characteristics and to use the quality of wood as a criterion for timber tree selection in thinning. Such information would require a larger number of trees to be sampled.

\subsection{Models proposed to estimate basic density and volumetric shrinkage}

The fixed effect estimates of the model explaining basic density indicate that the value increases with cambial age and decreases with increasing ring width, as expected (Tab. IV). Although the classical test application is only approximate in mixed models, the random effect variances were non zero ( $p=0.069)$ and indicate that the intercept of the model of wood density differs among trees. Parallel results were obtained (Tab. V) for the model explaining the variation of volumetric shrinkage. In both cases, the signs associated with the explanatory variable $C A^{2}$ were negative, which is consistent with the results shown in Figure 4.

In the case of basic density, the variation explained by the fixed effects was $32.0 \%$, with an additional $20.5 \%$ explained by random effects. In the case of volumetric shrinkage, the variation explained by the fixed effects was $36.4 \%$, with an additional $19.6 \%$ explained by the random effects. These results 
Table IV. Estimation and precision of the estimation of the fixed effects, variance estimation, standard error and $Z$ test of the random effects in model explaining basic density variation.

\begin{tabular}{lllll}
\hline $\begin{array}{l}\text { Fixed } \\
\text { effect }\end{array}$ & Estimation & $\begin{array}{l}\text { Standard } \\
\text { error }\end{array}$ & $T$ test & Probability \\
\hline$a_{0}$ & 339.41 & 13.98 & 24.26 & $<0.0001$ \\
$a_{1}$ & 4.886 & 0.728 & 6.71 & $<0.0001$ \\
$a_{2}$ & -0.060 & 0.018 & -3.29 & 0.0011 \\
$a_{3}$ & 47.157 & 10.263 & 4.59 & $<0.0001$ \\
\hline Random & Estimation & Standard & $Z$ test & Probability \\
effect & & error & & \\
\hline Var $\left(\alpha_{i}\right)$ & 944.24 & 636.86 & 1.48 & 0.0691 \\
$\rho$ (residual & 0.668 & 0.034 & 19.82 & $<0.0001$ \\
autocorrelation) & & & & \\
Var $(\varepsilon)$ & 723.73 & 73.65 & 9.83 & $<0.0001$ \\
\hline
\end{tabular}

Table V. Estimation and precision of the estimation of the fixed effects, variance estimation, standard error and $Z$ test of the random effects in the model explaining variation in volumetric shrinkage.

\begin{tabular}{lllll}
\hline $\begin{array}{l}\text { Fixed } \\
\text { effect }\end{array}$ & Estimation & $\begin{array}{l}\text { Standard } \\
\text { error }\end{array}$ & $T$ test & Probability \\
\hline$b_{0}$ & 8.468 & 0.619 & 13.66 & $<0.0001$ \\
$b_{1}$ & 0.340 & 0.048 & 7.03 & $<0.0001$ \\
$b_{2}$ & -0.00525 & 0.00124 & -4.24 & $<0.0001$ \\
$b_{3}$ & 3.0387 & 0.7373 & 4.12 & $<0.0001$ \\
\hline Random & Estimation & Standard & $Z$ test & Probability \\
effect & & error & & \\
\hline Var $\left(\beta_{i}\right)$ & 1.417 & 0.966 & 1.47 & 0.0712 \\
$\rho$ (residual & 0.494 & 0.039 & 12.57 & $<0.0001$ \\
autocorrelation) & & & & \\
Var $(\varepsilon)$ & 2.87 & 0.227 & 12.64 & $<0.0001$ \\
\hline
\end{tabular}

indicate the importance of considering the random effects in modelling physical properties variation along the stem, as considered for Scots pine and other species (Mutz et al., 2004). It should be considered that, although no direct effect of height in the stem was considered in these models, the negative effect of ring width and the increase in basic density outward from the pith of the stem result in a necessary decrease in density from the base to the tree top, as considered in other models (Kellomäki et al, 1999).

\subsection{Conclusions}

Some $7 \%$ of the specimens contained wood 30 to $40 \%$ denser than expected - mostly located near the pith and at a low height in the stem - which was attributed to compression wood. Excluding these specimens, direct relationships between basic density and volumetric shrinkage with ring width and cambial age were observed. The relationship between physical properties and height in the stem appeared to be indirect and varied among trees. Important between-tree differences were observed for basic density, volumetric shrinkage and axial shrinkage. This led to the fitting of a model with random components for the intercept parameter to predict cam- bial age, which accounted for $52.5 \%$ of the total variance, and volumetric shrinkage, which explained $56 \%$ of the variance.

Significant positive relationships between different transverse shrinkage variables and volumetric shrinkage, and a negative relationship between radial shrinkage and ring width were observed. The intra-tree relationships between transverse and longitudinal shrinkage and other variables were not always clear.

\section{REFERENCES}

Aguiar A., Almeida M.H., and Borralho N., 2003. Genetic control of growth, wood density and stem characteristics of Pinus pinaster in Portugal. Silva Lusitana 11: 131-139.

Bravo-Oviedo A., Sterba H., del Río M., and Bravo F., 2006. Competition-induced mortality for Mediterranean Pinus pinaster Ait. and Pinus sylvestris L. For. Ecol. Manage. 222: 88-98.

DGCONA, 2002. Tercer Inventario Forestal Nacional 1997-2006. Galicia, Lugo, Orense. Ministerio de Medio Ambiente, Madrid.

Fernández-Golfín J.I. and Díez Barra M R., 1994. Influencia de la anchura del anillo de crecimiento en la densidad y otras propiedades físicomecánicas de la madera estructural de diversas especies. Investig. Agrar.: Sist. Recur. For. 3: 211-219.

Fernández-Golfín J.I., Díez Barra M.R., and Gutiérrez Oliva A., 1997. Caracterización mecánica de la madera aserrada de pino silvestre de los Sistemas Central e Ibérico mediante probetas de tamaño estructural. Investig. Agrar.: Sist. Recur. For. 6: 183-214.

Forest Products Laboratory, 1999. Wood handbook. Wood as an engineering material. Gen. Tech. Rep. FPL-GTR-113, USDA, Forest Service, Madison.

Gjerdrum P., 2003. Heartwood in relation to age and growth rate in Pinus sylvestris L. in Scandinavia. Forestry 76: 413-424.

Gómez Loranca J.A., Gutiérrez Oliva A., and Baonza Merino M.V., 1996. Influencia de la intensidad de clara en el crecimiento, producción y características de la madera en una masa artificial de Pinus sylvestris L. Investig. Agrar.: Sist. Recur. For. 5: 257-273.

Guilley E., Hervé J.C., and Nepveu G., 2004. The influence of site quality, silviculture and region on wood density mixed model in Quercus petraea Liebl. For. Ecol. Manage. 189: 11-121.

Guller B., 2007. The effects of thinning treatments on density, MOE, MOR and maximum crushing strength of Pinus brutia Ten. wood. Ann. For. Sci. 64: 467-475.

Gutiérrez Oliva A., Baonza Merino M.V., and Fernández-Golfín J.I., 1997. Variaciones de la densidad de la madera de pino silvestre de los Sistemas Central e Ibérico. In: Proceedings of I Congreso Forestal Hispano-Luso, IRATI 97. SECF, Pamplona, pp. 229-234.

Gutiérrez Oliva A. and Plaza F., 1967. Características físico-mecánicas de las maderas españolas. IFIE, Madrid.

Jayawickrama K.J.S., 2001. Breeding radiata pine for wood stiffness: review and analysis. Aust. For. 64: 51-56.

Kellomäki S., Ikonen V.P., Peltola H., and Kolström T., 1999. Modelling the structural growth of Scots pine with implications for wood quality. Ecol. model. 27: 117-134.

Kininmonth J.A. and Whitehouse L.J., 1991. Properties and uses of New Zealand radiata pine, vol. I, Wood properties. Ministry of Forestry, FRI, Christchurch.

Kollmann F., 1951. Technologie des Holzes und der Holzwerkstoffe. Vol. I, Springer Verlag, Berlin. 
Littell R.C., Milliken G.A., Stroup W.W., and Wolfinger R.D., 1996. SAS System for Mixed Models. SAS Institute, Cary, NC, 633 p.

Louzada J.L.P.C., 1991. Variaçao nas componentes da densidade na madeira de Pinus pinaster Ait. Série Técnica-Científica, 12. UTAD, Vila Real.

Louzada J.L.P.C., 2003. Genetic correlations between wood density components in Pinus pinaster Ait. Ann. For. Sci. 60: 285-294.

Louzada J.L.P.C. and Fonseca F.M.A., 1991. Influência do crescimento em diâmetro (DAP) e da qualidade do local na variaçao da densidade em Pseudotsuga menziesii Mirb. (Franco). Série Técnica-Científica, 10. UTAD, Vila Real.

Malcolm D.C., 1997. The silviculture of conifers in Great Britain. Forestry 70: 293-308.

Martínez Chamorro E., 2004. Estudio del crecimiento, producción y gestión de las masas de Pinus sylvestris L. en Galicia. Ph. D. thesis, Universidad de Santiago de Compostela.

Mazet J.F. and Nepveu G., 1991. Relations between wood shrinkage properties and wood density for Scots pine, silver fir and Norway spruce. Ann. Sci. For. 48: 87-100.

Montero G., Cañellas I., Ortega C., and del Río M., 2001. Results from a thinning experiment in a Scots pine (Pinus sylvestris L.) natural regeneration stand in the Sistema Ibérico Mountain Range (Spain). For. Ecol. Manage. 145: 151-161.

Mörling T., 2002. Evaluation of annual ring width and ring density development following fertilisation and thinning of Scots pine. Ann. For. Sci. 59: 29-40.

Mörling T. and Valinger E., 1999. Effects of fertilization and thinning on heartwood area, sapwood area and growth in Scots pine. Scand. J. For. Res. 14: 462-469.
Mutz R., Guilley E., Sauter U.H., and Nepveu G., 2004. Modelling juvenile-mature wood transition in Scots pine (Pinus sylvestris L.) using nonlinear mixed-effects models. Ann. For. Sci. 61: 831-841.

Nájera F. and Peraza C., 1960. Características fisico-mecánicas del pino silvestre en España. Anales del IFIE 5: 83-107.

Panshin A.J. and de Zeeuw C., 1980. Textbook of wood technology, Mc Graw Hill, New York.

Riekkinen M., Nevalainen S., and Verkasalo E., 2005. Competitive properties of Scots pine from Nordic countries in mechanical wood processing. METLA. Results of projects in the SPWT consortium. Internal report. Joensuu, Finland.

Rijsdijk J.F. and Laming P.B., 1994. Physical and related properties of 145 timbers: information for practice. Kluwer Academic Publishers, Dordrecht.

Rojo A., Diéguez U., Rodríguez Soalleiro R., and Gadow K., 2005. Modelling silvicultural and economic alternatives for Scots pine (Pinus sylvestris L.) plantations in north-western Spain. Forestry 78: 385-401.

Rune G., Warensjö M., 2002. Basal sweep and compression wood in young Scots pine trees. Scand. J. For. Res. 17: 529-537.

SAS Institute Inc., 2004. SAS/STAT 9.1. User's guide. SAS Institute Inc., Cary, NC.

West P.W., 2006. Growing plantation forests. Springer Verlag, Berlin.

Zobel B.J. and van Buijtenen J.P., 1989. Wood variation. Its causes and control. Springer Verlag, Berlin. 